\title{
Voici à quoi ressemblera un article scientifique si on continue à précariser les métiers de la recherche
}

\section{Revues en lutte}

\section{(2) OpenEdition}

\section{Journals}

Édition électronique

URL : http://journals.openedition.org/pa/841

DOI : 10.4000/pa.841

ISSN : 2273-0362

Éditeur

Université Lumière Lyon 2

Référence électronique

Revues en lutte, « Voici à quoi ressemblera un article scientifique si on continue à précariser les métiers de la recherche », Parcours anthropologiques [En ligne], 14 | 2020, mis en ligne le 19 mars 2020, consulté le 04 septembre 2020. URL : http://journals.openedition.org/pa/841 ; DOI : https://doi.org/ 10.4000/pa.841

Ce document a été généré automatiquement le 4 septembre 2020.

Parcours anthropologiques 


\section{Voici à quoi ressemblera un article scientifique si on continue à précariser les métiers de la recherche}

Revues en lutte

\section{Revues en lutte}



Voici à quoi ressemblera un article scientifique si on continue à précariser les métiers de la recherche.

@RevuesInLutte / com_mob_revues@framalistes.org 